\title{
Effects of nutrient enrichment on decomposition and fungal colonization of sweet chestnut leaves in an Iberian stream (Central Portugal)
}

\author{
Manuela Abelho ${ }^{1,2, *}$ \& M.A.S. Graça ${ }^{2}$ \\ ${ }^{1}$ Escola Superior Agrária, Instituto Politécnico de Coimbra, 3040-316, Coimbra, Portugal \\ ${ }^{2}$ IMAR - Centro Interdisciplinar de Coimbra, Departamento de Zoologia da Universidade de Coimbra, Largo Marquês de \\ Pombal, 3004-517, Coimbra, Portugal \\ (*Author for correspondence: E-mail: abelho@esac.pt; abelho@ci.uc.pt)
}

Received 25 May 2005; in revised form 31 October 2005; accepted 5 November 2005

Key words: aquatic fungi, streams, nitrogen, phosphorus, leaf breakdown, fungal biomass, ergosterol, sporulation rates, nutrient enrichment, 3rd order stream, Central Portugal

\begin{abstract}
This study assessed the effect of nutrient enrichment on rates of decomposition, ergosterol concentrations (as a measure of fungal biomass), and rates of fungal sporulation of sweet chestnut (Castanea sativa Miller) leaves in a 3rd order stream (Central Portugal), with medium to high background values of nutrients. Coarse and fine mesh leaf bags were attached to nutrient diffusing substrata containing $\mathrm{NaNO}_{3}, \mathrm{KH}_{2} \mathrm{PO}_{4}$, both nutrients, or no additions. Leaf breakdown rates were similar in the four treatments and in the two mesh sizes $\left(k=-0.0155\right.$ to -0.0219 day $\left.^{-1}\right)$. Phosphorus content of $\mathrm{P}$ or $\mathrm{N}+\mathrm{P}$ enriched leaves was higher than in the other treatments after 28 days, but there were no differences in $\mathrm{N}$ concentrations. Ergosterol concentrations associated with decomposing leaves were similar among treatments. The peak sporulation rates of aquatic hyphomycetes were stimulated by the addition of $\mathrm{N}+\mathrm{P}$ and $\mathrm{N}$ but not by $\mathrm{P}$ alone. Results from the experiment provide evidence that leaf breakdown in the study stream, as a model for streams with naturally medium to high level of nutrients, was not nutrient-limited, and that fungal reproductive activity was limited by dissolved $\mathrm{N}$ but not by dissolved $\mathrm{P}$ in stream water.
\end{abstract}

\section{Introduction}

Unpolluted forested streams often have low concentrations of dissolved nutrients, particularly $\mathrm{N}$ and $\mathrm{P}$. When adequate light is available, nutrient enrichment usually enhances algal growth and rates of primary production in streams (Fairchild \& Lowe, 1984; Thomas \& Daldorph, 1994; Tank \& Winterbourn, 1996; Scrimgeour \& Chambers, 1997), showing that autotrophic production is nutrient-limited (N, P or both) in many streams (Stockner \& Shortreed, 1978; Elwood et al., 1981; Peterson et al., 1983; Friberg \& Winterbourn, 1997; Perrin \& Richardson, 1997). The effects of dissolved nutrients on rates of leaf decomposition, fungi and macroinvertebrates colonizing leaf litter are less predictable, because they may involve more complex interactions. Aquatic hyphomycetes, the most important leaf-decaying fungi in streams, can use nutrients dissolved in streamwater (Suberkropp \& Chauvet, 1995; Suberkropp, 1998; Grattan \& Suberkropp, 2001) and there is evidence that decomposition can also be regulated by dissolved nutrients, as shown by leaf decomposition studies in eutrophic streams (Royer \& Minshall, 1997), by the comparison of decomposition rates among streams differing in nutrient concentrations (Meyer \& Johnson, 1983; Suberkropp \& Chauvet, 1995), by transfer experiments (Suberkropp \& Chauvet, 1995), and by 
nutrient enrichment experiments (Elwood et al., 1981; Pearson \& Connolly, 2000; Shridhar \& Bärlocher, 2000; Grattan \& Suberkropp, 2001; Bärlocher \& Corkum, 2003; Chadwick \& Huryn, 2003; Gulis \& Suberkropp, 2003a, b). Other nutrient enrichment experiments have produced varying results. Robinson \& Gessner (2000) found no differences in fungal biomass or activity between fertilized and unfertilized leaf packs, suggesting that the faster breakdown of fertilized leaf packs was brought about by increased shredder colonization and feeding. Royer \& Minshall (2001) showed that the breakdown rates of three leaf species were unaffected by nutrient enrichment, suggesting that leaf breakdown was not nutrient-limited in that stream.

The main objective of this study was to determine whether dissolved inorganic nutrients $(\mathrm{P}, \mathrm{N}$ or both) limit activity of aquatic fungi colonizing sweet chestnut leaves (Castanea sativa Miller), thus influencing leaf breakdown rates. The experiment was carried out in a small, low order forested stream during summer. Instead of working in an extreme situation of very low levels of nutrients as reported in other publications, we selected a stream with average values of nitrogen, and relatively high levels of phosphorus content. Although we did not measure litter standing stock, similar streams in the same region had large amounts of CPOM standing stock during the whole year (Abelho \& Graça, 1996) and the transport of spores was not severely reduced during summer (Bärlocher et al., 1995; Bärlocher \& Graça, 2002). Leaves were attached to nutrient diffusing substrata with $\mathrm{N}, \mathrm{P}, \mathrm{N}+\mathrm{P}$ or no additions (control), and treatment effects on breakdown rates of leaves, ergosterol concentrations (as an estimate of fungal biomass), and rates of fungal sporulation were determined.

\section{Material and methods}

\section{Study site}

Fieldwork was conducted at Ribeira do Candal, a 3rd order stream located $24.5 \mathrm{~km}$ southeast of Coimbra in Central Portugal $\left(40^{\circ} 05^{\prime} \mathrm{N}\right.$, $\left.8^{\circ} 12^{\prime} \mathrm{W}\right)$, between June and August, 2000. The region is characterized by a moderate humid climate with mean annual precipitation ranging from 1200 to $1400 \mathrm{~mm}$ and high precipitation from the end of autumn to the beginning of spring. August is the driest month with an average precipitation of $21 \mathrm{~mm}$. Mean annual temperature varies between 12.5 and $15^{\circ} \mathrm{C}$, with highest values (up to $37.5^{\circ} \mathrm{C}$ ) recorded in August. The stream was heavily shaded by mixed deciduous riparian vegetation, with sweet chestnut as the dominant tree. The experiment was conducted at three discrete riffles over a length of $30 \mathrm{~m}$. Despite the deficit of water during summer, the stream had flowing water with stable depth (circa $20 \mathrm{~cm}$ at the studied section) throughout the experimental period. Mean current velocity was $0.31 \mathrm{~m} \mathrm{~s}^{-1}$ and mean discharge was $0.014 \mathrm{~m}^{3} \mathrm{~s}^{-1}$. Before the experiment, ambient concentration of soluble reactive phosphorus (SRP) in the stream was $29 \mu \mathrm{g}^{-1}$, and total dissolved nitrogen concentration was $279 \mu \mathrm{g}^{-1}$ (as $\mathrm{NO}_{2}-\mathrm{N}+\mathrm{NO}_{3}-\mathrm{N}+\mathrm{NH}_{4}$ $\mathrm{N})$. There were no significant differences between treatments in SRP and total $\mathrm{N}$ of the stream water during the study period $(\mathrm{DF}=3, F<0.2, p>0.893$; Fig. 1). Other characteristics of the stream water are shown in Table 1.

\section{Nutrient diffusing substrata (NDS)}

The nutrient diffusing substrata consisted of clay pots (length $12.5 \mathrm{~cm}$, width $9 \mathrm{~cm}$, height $4 \mathrm{~cm}$, and internal volume ca. $350 \mathrm{ml}$ ). Each pot was soaked in deionized-distilled water during one week, dried, filled with agar or nutrient-agar solution, and glued to a polypropylene base with aquarium safe silicon. One margin of each polypropylene base was pierced to allow the attachment of the NDS to the stream bottom with a nail.

\section{Agar-nutrient solutions}

The four treatments used in the experiment were: control (C) in which no nutrients were added, $\mathrm{N}$ added as $1 \mathrm{M}$ sodium nitrate $\left(85 \mathrm{~g} \mathrm{l}^{-1} \mathrm{NaNO}_{3}\right), \mathrm{P}$ added as $1 \mathrm{M}$ dihydrogen phosphate $\left(136.1 \mathrm{~g} \mathrm{l}^{-1}\right.$ $\mathrm{KH}_{2} \mathrm{PO}_{4}$ ), and $\mathrm{N}+\mathrm{P}$ added as $1 \mathrm{M} \mathrm{NaNO}_{3}$ and $1 \mathrm{M} \mathrm{KH_{2 }} \mathrm{PO}_{4}$. Nutrients were added as agarnutrient solutions in clay pots to which the leaf bags were attached. After removal from the autoclave, agar solutions $\left(12 \mathrm{~g}^{-1}\right.$ in distilled water) were stirred continuously until cooled to 

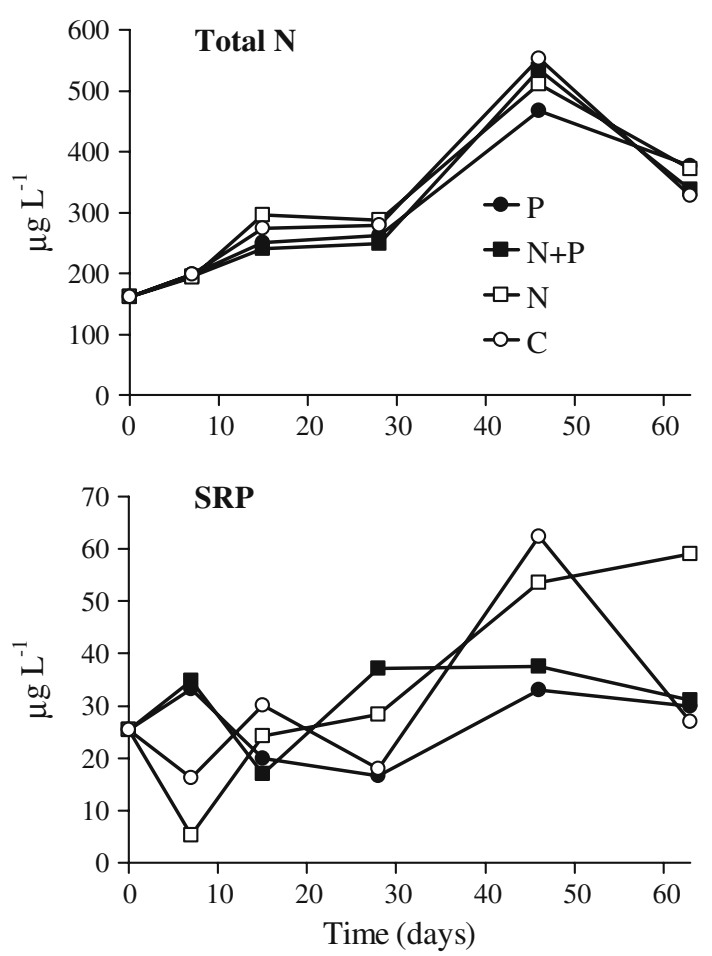

Figure 1. Temporal variation in soluble reactive phosphorus (SRP) and total dissolved nitrogen (as $\mathrm{NO}_{2}-\mathrm{N}+\mathrm{NO}_{3}-\mathrm{N}+\mathrm{NH}_{4}{ }^{-}$ $\mathrm{N})$ of stream water below each treatment during the study period.

about $60{ }^{\circ} \mathrm{C}$ before nutrients were added. After complete dissolution the agar-nutrient solutions were poured into the clay pots and allowed to cool completely before attachment to the polypropylene bases. Since the agar solution is partially absorbed into the clay pot walls, $400 \mathrm{ml}$ was typically poured into each clay pot.

\section{Leaf bags}

Leaves were collected in the previous fall just prior to abscission from sweet chestnut trees and air-

Table 1. Stream water characteristics during the study

\begin{tabular}{lccc}
\hline Parameter & Mean & Range & $N$ \\
\hline $\mathrm{DO}(\%)$ & 94.8 & $90.0-100.0$ & 6 \\
$\mathrm{mg} \mathrm{O}_{2} 1^{-1}$ & 10.3 & $9.9-10.7$ & 6 \\
Temperature $\left({ }^{\circ} \mathrm{C}\right)$ & 14.6 & $13.2-15.3$ & 6 \\
Conductivity $\left(\mu \mathrm{S} \mathrm{cm}^{-1}\right)$ & 42.4 & $36.5-50.9$ & 5 \\
$\mathrm{pH}$ & 6.7 & $6.2-7.3$ & 5 \\
\hline
\end{tabular}

dried at room temperature until needed. Air-dried leaves (mean $2.14 \mathrm{~g}$, range $2.10-2.19 \mathrm{~g}$ ) were enclosed into fine $(0.5 \mathrm{~mm})$ or coarse $(5 \mathrm{~mm})$ mesh bags to exclude or allow for macroinvertebrate colonization. The conversion factor to calculate initial ash free dry mass (AFDM) from air-dry mass of leaves was obtained from additional 18 samples that were dried $\left(60^{\circ} \mathrm{C}, 3\right.$ days), weighed $( \pm 0.01 \mathrm{~g})$, ashed $\left(500^{\circ} \mathrm{C}, 5 \mathrm{~h}\right)$ and reweighed.

\section{Field experiment}

Fine $(0.5 \mathrm{~mm})$ and coarse $(5 \mathrm{~mm})$ mesh bags were filled with chestnut leaves and attached to the NDS with nylon ropes. A total of 15 replicate NDS of each treatment and mesh size were attached to the stream substratum in each of three discrete riffles. To avoid interference of compounds leached from upstream NDS, each treatment was separated by approximately $1.5 \mathrm{~m}$ along the direction of the flow. The treatments were ordered downstream as follows: control, treatment $\mathrm{N}$ and treatment $\mathrm{P}$ side by side and treatment $\mathrm{N}+\mathrm{P}$. Treatment $\mathrm{N}$ and treatment $\mathrm{P}$ were attached at the same riffle, within two separate channels artificially created with stones.

In a preliminary laboratory experiment, the NDS progressively released nutrients to the water, taking approximately 28 days to decrease initial release rates by half. To avoid low release rates at the end of the study, NDS were replaced at day 28 , after sampling. The leaf bags were carefully removed from the old NDS, attached to the new ones, and maintained submerged while changing the NDS, so that the biota was as little affected as possible.

Leaf bags were retrieved at 7, 15, 28, 46 and 63 days after placement in the stream. Three replicates of each treatment and mesh size were randomly taken and individually transported to the laboratory in stream water.

\section{Response variables and laboratory procedures}

The response variables assessed in this study were: (1) leaf AFDM remaining, (2) N and P content of leaves, (3) ergosterol concentrations associated with leaves, and (4) sporulation rate of aquatic hyphomycetes. 
In the laboratory, leaves were gently washed with tap water to remove macroinvertebrates and attached debris. From each sample, three sets of eight leaf discs (12 $\mathrm{mm}$ diameter) were cut to determine ergosterol concentrations, sporulation rate and AFDM. The remaining leaf material was used to determine AFDM and nutrient ( $\mathrm{N}$ and $\mathrm{P}$ ) concentrations. AFDM of the remaining leaf material was corrected for the mass of the three sets of leaf discs.

Leaf discs for ergosterol analyses were allocated to $20 \mathrm{ml}$ scintillation vials containing $5 \mathrm{ml}$ methanol and stored at $-20{ }^{\circ} \mathrm{C}$ until analyzed with the procedure described by Gessner \& Schmitt (1996). Lipids were extracted with hot alkaline methanol and the lipid extract was purified by solid-phase extraction (SPE). Ergosterol was separated and quantified by high performance liquid chromatography (HPLC).

Leaf discs for determination of sporulation rates of aquatic hyphomycetes were allocated to $100 \mathrm{ml}$ Erlenmeyer flasks containing $50 \mathrm{ml}$ distilled water and agitated for $36 \mathrm{~h}\left(15^{\circ} \mathrm{C}, 90 \mathrm{rpm}\right)$. The water was filtered $(0.8 \mu \mathrm{m}$ membrane filters, Millipore); the filters were stained with cotton blue in lactic acid and stored until analyzed. Conidia were counted in 4-15 $($ mean $=9)$ microscopic fields (area $0.166 \mathrm{~mm}^{2}$ ) at $400 \times$. Sporulation rates were calculated as number of conidia $\mathrm{mg}^{-1}$ AFDM d $\mathrm{d}^{-1}$.

Percent nitrogen and phosphorus of leaves were determined on oven dried ground sub-samples. Percent nitrogen was determined on a ThermoQuest CE Instruments NC2100 Elemental Analyzer. Total phosphate was determined by combustion at $500{ }^{\circ} \mathrm{C}$ for $1 \mathrm{~h}$, followed by addition of $1 \mathrm{~N} \mathrm{HCl}$ and incubation at $80{ }^{\circ} \mathrm{C}$ for $30 \mathrm{~min}$. After dilution aliquots were analyzed for $\mathrm{PO}_{4}-\mathrm{P}$ with a Technicon AutoAnalyzer.

\section{Statistical analyses}

Decomposition rates $(k)$ were calculated as the slope of linear regressions of time in days and the natural logarithm of percent AFDM remaining, with AFDM at day 0 set at $100 \%$. Differences in decomposition rates were determined using analysis of covariance (ANCOVA) with differences in slopes determined with Tukey's multiple comparisons (Zar, 1999). Treatment and mesh size effects on nutrient content ( $\mathrm{N}$ and $\mathrm{P}$ ) of leaves, ergosterol and sporulation rates were determined by repeated measures two-way analysis of variance (ANOVA). Two-way ANOVA was also used to test for the effect of mesh size and treatment on specific sampling dates. Data counts were $\log (\mathrm{x}+1)$ transformed before proceeding with parametric testing (Zar, 1999). If significant differences were found, Bonferroni multiple comparisons were performed to determine which samples differed. All null hypotheses were rejected if $p<0.05$. ANOVAs were performed on SPSS for Windows, version 11.0.

\section{Results}

\section{Decomposition rates and leaf chemistry}

Decomposition rate of the leaves was not stimulated by the addition of nutrients, either alone or in combination (Table 2, Fig. 2). After 2 months, mean AFDM remaining varied between $27 \%$ and $38 \%$ across treatments and mesh sizes (Fig. 2).

The leaf $\mathrm{N}$ content increased throughout the experiment in all treatments and in both mesh sizes (Fig. 3). Although there was a tendency towards higher $\mathrm{N}$ content in leaves enriched with nitrogen, the effect of mesh size or treatment was not significant (Table 3 ). The content of $\mathrm{P}$ in leaves decreased significantly during the first 15-28 days in the stream, increasing afterwards through the end of the experiment, so that the final values were as high as the initial ones (Fig. 3). There was a significant effect of treatment on leaf $\mathrm{P}$ content; leaves enriched with phosphorus had higher $\mathrm{P}$ content than leaves that did not receive enrichment, but the difference was only significant for days 28 and 63 (Table 3). On day 28, \%P of leaves was significantly higher in fine than in coarse mesh bags (Table 3 ).

\section{Fungal colonization and activity}

Ergosterol concentrations peaked on day 28 in all treatments, except in treatment $\mathrm{P}$ of fine mesh bags, where they increased until the end of the experiment (Fig. 4). Ergosterol concentrations were significantly different between the two mesh sizes, but there was no significant effect of treatment (Table 3). The effect of mesh was significant 
Table 2. Decomposition rates $(k)$ of sweet chestnut leaves in treatments of each mesh size

\begin{tabular}{lll}
\hline Treatment & Fine mesh $( \pm$ SE $)$ & Coarse mesh $( \pm$ SE $)$ \\
\hline Control & $-0.01797 \pm 0.00115$ & $-0.02192 \pm 0.00224^{\mathrm{a}}$ \\
$\mathrm{N}$ & $-0.01547 \pm 0.00069^{\mathrm{a}}$ & $-0.01992 \pm 0.00211$ \\
$\mathrm{P}$ & $-0.01644 \pm 0.00113$ & $-0.01632 \pm 0.00052$ \\
$\mathrm{~N}+\mathrm{P}$ & $-0.01741 \pm 0.00077$ & $-0.02045 \pm 0.00168$ \\
\hline
\end{tabular}

${ }^{\mathrm{a}}$ Decay rates with the same letter are significantly different $(p<0.05)$ using Tukey's multiple comparisons for differences among slopes, following a significant ANCOVA.

only for day 15 (Table 3), when ergosterol concentrations started to peak.

Sporulation rate was not affected by mesh size, but was affected by treatment and mesh*treatment interaction was also significant (Table 3). Sporulation rate of aquatic hyphomycetes peaked on day 15 for most of the treatments in both mesh sizes and was higher in treatment $\mathrm{N}+\mathrm{P}$ (Table 3). Mean sporulation rates on day 15 (across both mesh sizes) were 50187 and 11890 conidia per mg
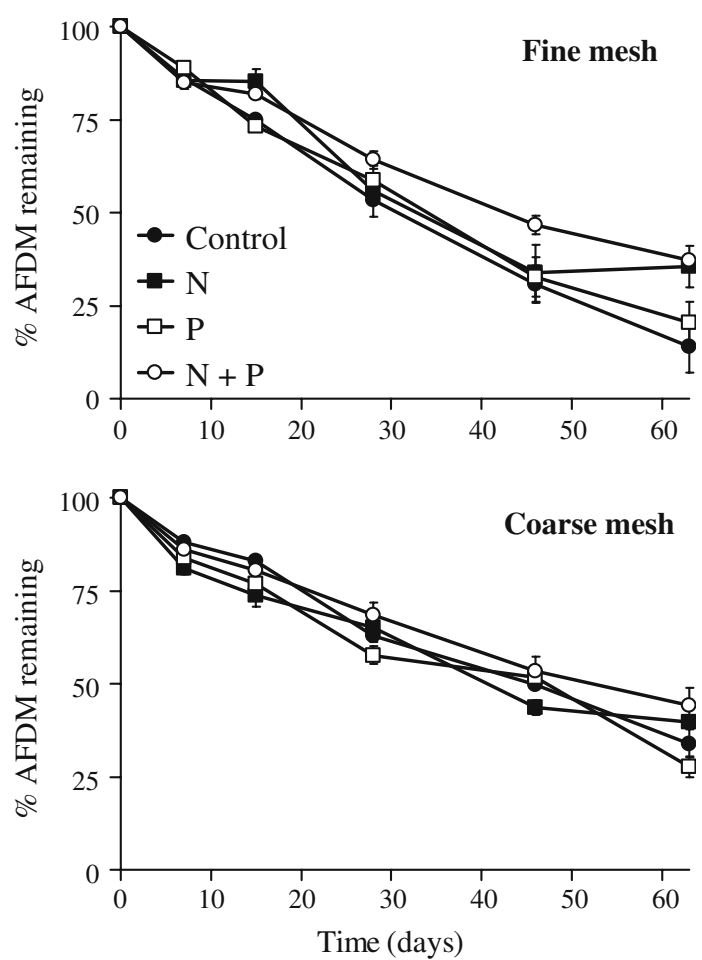

Figure 2. Percentage of initial ash-free dry mass remaining of sweet chestnut leaves in the four treatments in fine and coarse mesh bags (mean $\pm 1 \mathrm{SE}$ ).
AFDM per day in treatment $\mathrm{N}+\mathrm{P}$ and the control, respectively (Fig. 5). Sporulation rates in fine mesh bags peaked on day 15 in all enriched treatments while in the control they reached peak values only on day 28 . In the coarse mesh bags, an earlier and higher peak was evident in treatment $\mathrm{N}+\mathrm{P}$ (Fig. 5).

\section{Discussion}

\section{Leaf decomposition}

Rates of leaf decomposition and fungal biomass were not nutrient-limited in this stream. Our results are similar in this respect to findings by other authors who have reported that heterotrophic decomposers in streams do not respond to added dissolved nutrients (Robinson \& Gessner, 2000) or that leaf breakdown is not increased by nutrient enrichment (Royer \& Minshall, 2001). However, Robinson \& Gessner (2000) found that nutrients stimulated alder leaf breakdown in coarse mesh bags in an alpine brook, which they attributed to the increased abundance and biomass of shredders associated with enriched leaves. Other authors have found increased decomposition rates with the addition of nutrients (Elwood et al., 1981; Shridhar \& Bärlocher, 2000; Grattan \& Suberkropp, 2001; Gulis \& Suberkropp, 2003a), suggesting N + P or P (depending on ambient concentrations of nutrients in stream water) limitation (Elwood et al., 1981; Grattan \& Suberkropp, 2001).

\section{Fungal growth and sporulation}

Fungal biomass and sporulation of aquatic hyphomycetes associated with decomposing leaves in streams typically increase to a maximum and then decline through time (Gessner \& Chauvet, 1994; Weyers \& Suberkropp, 1996; Grattan \& Suberkropp, 2001). In our experiment both variables followed this pattern. Peaks in fungal biomass occurred between 15 and 28 days of decomposition while peaks in sporulation rates occurred earlier, between 7 and 15 days, suggesting that aquatic hyphomycetes invest considerable resources in reproduction very early in their life cycle. In a laboratory experiment, Shridhar \& Bärlocher (2000) showed that fungal 

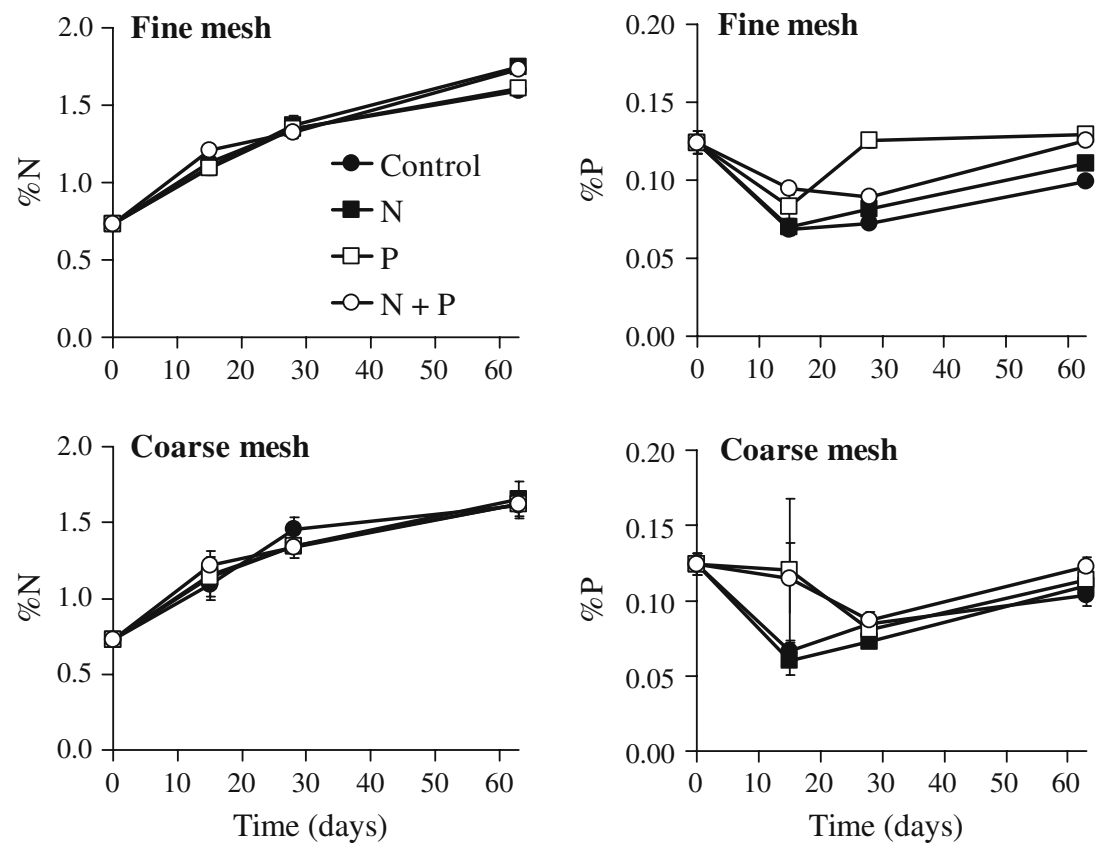

Figure 3. N (left) and P (right) contents of sweet chestnut leaves in the four treatments in fine and coarse mesh bags (mean $\pm 1 \mathrm{SE}$ ).

Table 3. Results of repeated measures and two-way ANOVAs for ergosterol concentrations, sporulation rates, and $\% \mathrm{~N}$ and $\% \mathrm{P}$ of the leaves. Treatments with the same letter are significantly different $(p<0.05)$ following Bonferroni post-hoc testing

\begin{tabular}{|c|c|c|c|c|c|}
\hline & Source & $\mathrm{DF}$ & $F$ & $p$ & Bonferroni \\
\hline \multirow[t]{3}{*}{ Ergosterol } & Mesh & 1 & 9.5 & 0.012 & \\
\hline & Treatment & 3 & 0.7 & 0.586 & \\
\hline & Mesh*Treatment & 3 & 0.9 & 0.486 & \\
\hline Day 15 & Mesh & 1 & 8.3 & 0.016 & \\
\hline \multirow{3}{*}{ Sporulation } & Mesh & 1 & 4.0 & 0.101 & \\
\hline & Treatment & 3 & 30.1 & 0.001 & $\mathrm{~N}+\mathrm{P}^{\mathrm{ab}}>\mathrm{N}^{\mathrm{ab}}>\mathrm{P}^{\mathrm{a}}>\mathrm{C}^{\mathrm{b}}, p<0.037$ \\
\hline & Mesh*Treatment & 2 & 12.0 & 0.012 & \\
\hline \multirow[t]{3}{*}{ Day 15} & Mesh & 1 & 17.0 & 0.009 & \\
\hline & Treatment & 3 & 66.6 & 0.000 & $\mathrm{~N}+\mathrm{P}^{\mathrm{ab}}>\mathrm{N}^{\mathrm{ab}}>\mathrm{P}^{\mathrm{a}}>\mathrm{C}^{\mathrm{b}}, p<0.018$ \\
\hline & Mesh*Treatment & 2 & 23.9 & 0.003 & \\
\hline \multirow[t]{3}{*}{$\% \mathrm{~N}$ of leaves } & Mesh & 1 & 0.076 & 0.787 & \\
\hline & Treatment & 3 & 0.171 & 0.915 & \\
\hline & Mesh*Treatment & 3 & 0.115 & 0.950 & \\
\hline \multirow[t]{3}{*}{$\% \mathrm{P}$ of leaves } & Mesh & 1 & 0.039 & 0.846 & \\
\hline & Treatment & 3 & 10.571 & 0.001 & $\mathrm{P}^{\mathrm{ab}}>\mathrm{N}+\mathrm{P}^{\mathrm{cd}}>\mathrm{N}^{\mathrm{ac}}>\mathrm{C}^{\mathrm{bd}}, p<0.025$ \\
\hline & Mesh*Treatment & 3 & 0.347 & 0.792 & \\
\hline \multirow[t]{3}{*}{ Day 28} & Mesh & 1 & 17.464 & 0.001 & \\
\hline & Treatment & 3 & 21.569 & 0.000 & $\mathrm{P}^{\mathrm{abc}}>\mathrm{N}+\mathrm{P}^{\mathrm{ad}}>\mathrm{C}^{\mathrm{b}}>\mathrm{N}^{\mathrm{cd}}, p<0.044$ \\
\hline & Mesh*Treatment & 3 & 18.947 & 0.000 & \\
\hline Day 63 & Treatment & 3 & 7.888 & 0.002 & $\mathrm{~N}+\mathrm{P}^{\mathrm{a}}>\mathrm{P}^{\mathrm{b}}>\mathrm{N}>\mathrm{C}^{\mathrm{ab}}, p<0.008$ \\
\hline
\end{tabular}



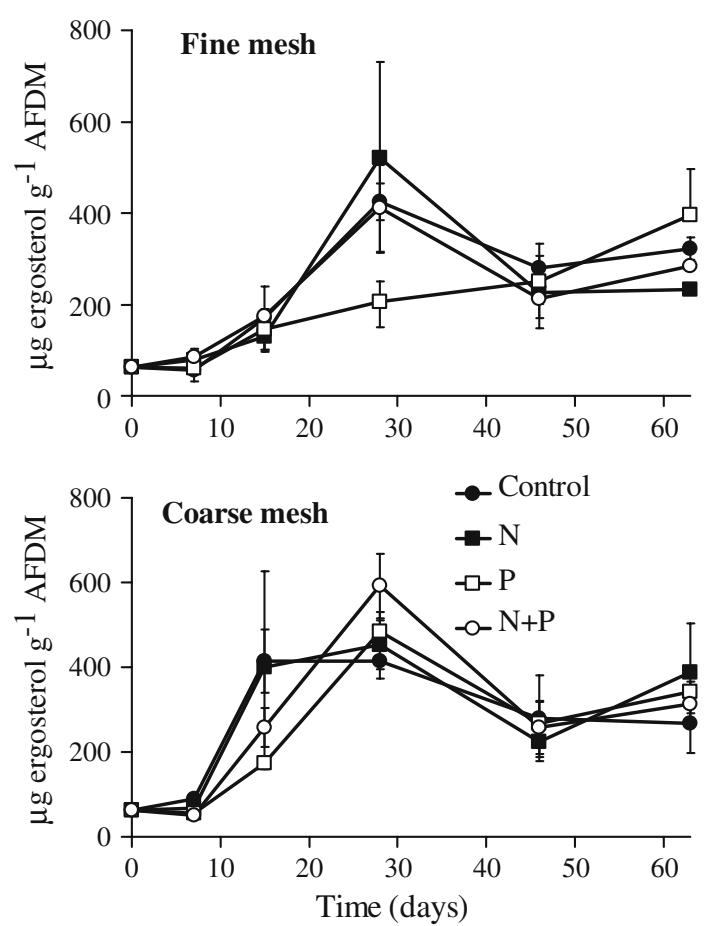

Figure 4. Ergosterol concentrations associated with sweet chestnut leaves in the four treatments in fine and coarse mesh bags (mean $\pm 1 \mathrm{SE})$.

investment in conidia exceeded investment in mycelium. The effect of dissolved nutrients was only apparent for sporulation rate of aquatic hyphomycetes, and only around its peak, confirming the suggestion of Suberkropp (1998) that $\mathrm{N}$ and $\mathrm{P}$ taken from the water are primarily shunted into sporulation and fungal sporulation is more sensitive to changes in nutrient concentration than growth (Suberkropp, 1995; Suberkropp, 1998; Grattan \& Suberkropp, 2001; Gulis \& Suberkropp, 2003a). Fungi sporulating at high rates may convert a significant portion of their production into conidia (Suberkropp, 1991; Shridhar \& Bärlocher, 2000). Since reproduction is one of the main outputs of production in aquatic hyphomycetes, stimulation of sporulation rates may mask increases in biomass.

Grattan \& Suberkropp (2001) found that the effect of nutrient enrichment on fungal sporulation rates varied with ambient concentration of dissolved nutrients in stream water. In streams with low concentrations of both $\mathrm{N}\left(<40 \mu \mathrm{g} \mathrm{1^{-1 }}\right)$ and $\mathrm{P}\left(<16 \mu \mathrm{g} \mathrm{l}^{-1}\right)$, sporulation rates were stimu- lated only when $\mathrm{N}$ and $\mathrm{P}$ were added together, indicating that both nutrients were limiting fungal activity. In a stream with low $\mathrm{P}\left(<5 \mu \mathrm{g}^{-1}\right)$ but high $\mathrm{N}\left(65-200 \mu \mathrm{g}^{-1}\right)$ concentrations, sporulation rates were stimulated by $\mathrm{P}$ addition and when both nutrients were added together, indicating limitation of fungal activity by P. In our study, sporulation rate was enhanced by the addition of $\mathrm{N}+\mathrm{P}$ and $\mathrm{N}$ but not $\mathrm{P}$ alone, indicating limitation of fungal reproductive activity by $\mathrm{N}$ but not $\mathrm{P}$, although the ambient dissolved nutrients in stream water were higher than those reported by Grattan \& Suberkropp (2001): $\mathrm{SRP}=29 \mu \mathrm{g}^{-1}$ and total $\mathrm{N}=279 \mu \mathrm{g}^{-1}$. This difference could be related to (1) the difference in season, (2) differences in leaf type, and (3) high enough $\mathrm{P}$ concentration to meet fungal needs. The study of Grattan \& Suberkropp (2001) was conducted during the maximum leaf fall. Abundant leaf litter may lower concentrations of $\mathrm{N}$ and $\mathrm{P}$ in streams, as a result of immobilization by leaf decomposing microorganisms (Mulholland, 1992; Mulholland \& Hill, 1997). Water velocity may also positively influence $\mathrm{PO}_{4}$
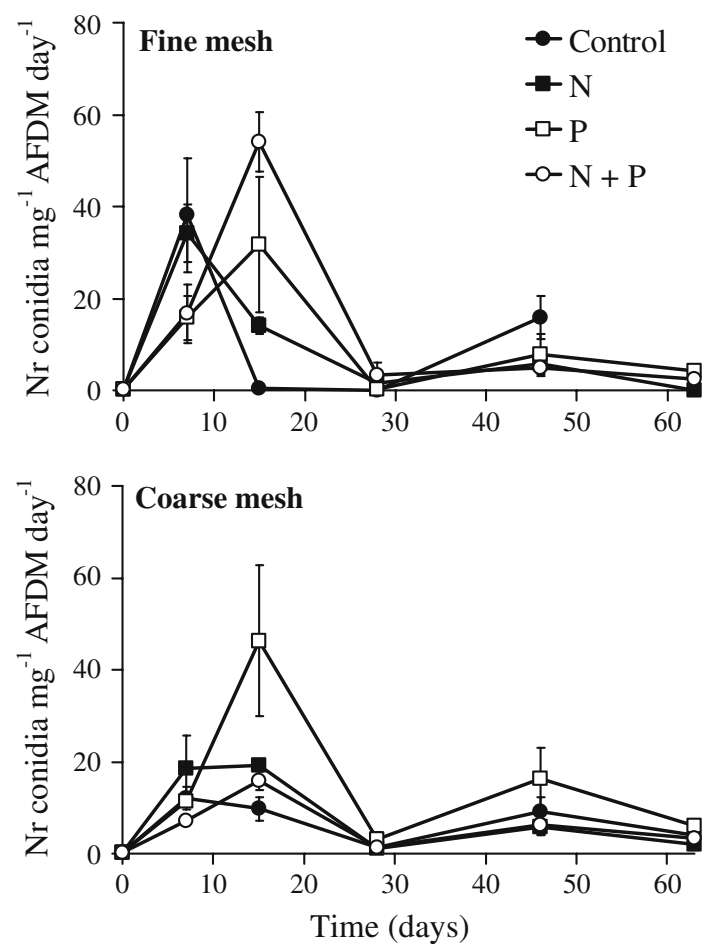

Figure 5. Sporulation rates of aquatic hyphomycetes associated with sweet chestnut leaves in the four treatments in fine and coarse mesh bags (mean $\pm 1 \mathrm{SE}$ ). 
uptake rate, as shown by Mulholland et al. (1985) in Walker Branch, Tennesse. Our study occurred during summer, coinciding with minimum discharge, minimum water velocity and minimum leaf fall, which may have contributed to the relatively high $\mathrm{P}$ content of the water. During minimum leaf fall period, phosphorus is thus less likely to be important to metabolic processes (Mulholland et al., 1985). Grattan \& Suberkropp (2001) used yellow poplar leaves while we used sweet chestnut; it is likely that microorganisms required different levels of nutrients if the chemical composition of leaves is different. Shridhar \& Bärlocher (2000) found that conidia production clearly increased at higher nutrient levels. However, the significant differences occurred only with $\mathrm{N}$ concentrations as high as $500 \mu \mathrm{g} \mathrm{NO}_{3} 1^{-1}$. On the other hand, the authors found no significant differences between different levels of $\mathrm{P}$ enrichment. These and our results suggest that $\mathrm{P}$ ambient concentration in our stream were enough to meet fungal needs and that $\mathrm{N}$ concentration, although relatively high, might still limit sporulation rates of aquatic hyphomycetes.

In conclusion, although the added nutrients resulted in increased $\mathrm{P}$ concentration of leaves, and enhanced fungal sporulation rates, these differences did not translate into faster breakdown rates. In response to enrichment, fungi invested more in reproduction instead of mycelial growth with no effects on leaf mass loss.

\section{Acknowledgements}

We thank John A. Craig and Jean-Luc E. Cartron (Department of Biology, University of New Mexico) for assistance with nutrient analyses of leaf samples, and for advice on statistical analyses, respectively. We also thank Vladislav Gulis (IMAR, University of Coimbra) and Chelsea Crenshaw (Department of Biology, University of New Mexico) for valuable comments on an earlier version of the manuscript.

\section{References}

Abelho, M. \& M. A. S. Graça, 1996. Effects of eucalyptus afforestation on leaf litter dynamics and macroinvertebrate community structure of streams in Central Portugal. Hydrobiologia 324: 195-204.

Bärlocher, F. \& M. Corkum, 2003. Nutrient enrichment overwhelms diversity effects in leaf decomposition by fungi in streams. Oikos 101: 247-252.

Bärlocher, F. \& M. A. S. Graça, 2002. Exotic riparian vegetation lowers fungal diversity but not leaf decomposition in Portuguese streams. Freshwater Biology 47: 1123-1136.

Bärlocher, F., C. Canhoto \& M. A. S. Graça, 1995. Fungal colonization of alder and eucalyptus leaves in two streams in Central Portugal. Archiv für Hydrobiologie 133: 457470.

Chadwick, M. A. \& A. D. Huryn, 2003. Effect of a wholecatchment $\mathrm{N}$ addition on stream detritus processing. Journal of the North American Benthological Society 22: 194-206.

Elwood, J. W., J. D. Newbold, A. F. Trimble \& R. W. Stark, 1981. The limiting role of phosphorus in a woodland stream ecosystem: effects of $\mathrm{P}$ enrichment on leaf decomposition and primary producers. Ecology 62: 146-158.

Fairchild, G. W. \& R. L. Lowe, 1984. Artificial substrates which release nutrients: effects on periphyton and invertebrate succession. Hydrobiologia 114: 29-37.

Friberg, N. \& M. J. Winterbourn, 1997. Effects of native and exotic forest on benthic stream biota in New Zealand: a colonization study. Marine and Freshwater Research 48: 267-275.

Gessner, M. O. \& E. Chauvet, 1994. Importance of stream microfungi in controlling breakdown rates of leaf litter. Ecology 75: 1807-1817.

Gessner, M. O. \& A. L. Schmitt, 1996. Use of solid-phase extraction to determine ergosterol concentrations in plant tissue colonized by fungi. Applied and Environmental Microbiology 62: 415-419.

Grattan, R. M. II \& K. Suberkropp, 2001. Effects of nutrient enrichment on yellow poplar leaf decomposition and fungal activity in streams. Journal of the North American Benthological Society 20: 33-43.

Gulis, V. \& K. Suberkropp, 2003a. Leaf litter decomposition and microbial activity in nutrient-enriched and unaltered reaches of a headwater stream. Freshwater Biology 48: $123-134$

Gulis, V. \& K. Suberkropp, 2003b. Effect of inorganic nutrients on relative contributions of fungi and bacteria to carbon flow from submerged decomposing leaf litter. Microbial Ecology 45: 11-19.

Meyer, J. L. \& C. Johnson, 1983. The influence of elevated nitrate concentration on rate of leaf decomposition in a stream. Freshwater Biology 13: 177-183.

Mulholland, P. J., 1992. Regulation of nutrient concentrations in a temperate forest stream: roles of upland, riparian, and instream processes. Limnology and Oceanography 37: 1512-1526.

Mulholland, P. J. \& W. R. Hill, 1997. Separating catchment flowpath and instream effects on stream nutrient and DOC concentrations: evidence from long-term data records. Water Resources Research 33: 1297-1306.

Mulholland, P. J., J. D. Newbold, J. W. Elwood \& J. R. Webster, 1985. Phosphorus spiraling in a woodland stream: seasonal variations. Ecology 66: 1012-1023. 
Pearson, R. G. \& N. M. Connolly, 2000. Nutrient enhancement, food quality and community dynamics in a tropical rainforest stream. Freshwater Biology 43: 31-42.

Perrin, C. J. \& J. S. Richardson, 1997. N and P limitation of benthos abundance in the Nechako River, British Columbia. Canadian Journal of Fisheries and Aquatic Sciences 54: 2574-2583.

Peterson, B. J., J. E. Hobbie, T. L. Corliss \& K. Kriet, 1983. A continuous-flow periphyton bioassay: tests of nutrient limitation in a tundra stream. Limnology and Oceanography 28: 583-591.

Robinson, C. T. \& M. O. Gessner, 2000. Nutrient addition accelerates leaf breakdown in an alpine springbrook. Oecologia 122: 258-263.

Royer, T. V. \& G. W. Minshall, 1997. Rapid breakdown of allochthonous and autochthonous plant material in a eutrophic river. Hydrobiologia 344: 81-86.

Royer, T. V. \& G. W. Minshall, 2001. Effects of nutrient enrichment and leaf quality on the breakdown of leaves in a hardwater stream. Freshwater Biology 46: 603-610.

Scrimgeour, G. J. \& P. A. Chambers, 1997. Development and application of a nutrient-diffusing bioassay for large rivers. Freshwater Biology 38: 221-231.

Shridhar, K. R. \& F. Bärlocher, 2000. Initial colonization, nutrient supply, and fungal activity on leaves decaying in streams. Applied and Environmental Microbiology 66: 1114-1119.

Suberkropp, K., 1991. Relationships between growth and sporulation of aquatic hyphomycetes. Mycological Research 101: 591-596.
Suberkropp, K., 1995. The influence of nutrients on fungal growth, productivity, and sporulation during leaf breakdown in streams. Canadian Journal of Botany 73: S1361-S1369.

Suberkropp, K., 1998. Effect of dissolved nutrients on two aquatic hyphomycetes growing on leaf litter. Mycological Research 102: 998-1002.

Suberkropp, K. \& E. Chauvet, 1995. Regulation of leaf breakdown by fungi in streams: influences of water chemistry. Ecology 76: 1433-1445.

Stockner, J. G. \& K. R. S. Shortreed, 1978. Enhancement of autotrophic production by nutrient addition in a coastal rainforest stream of Vancouver Island. Journal of the Fisheries Research Board of Canada 35: 28-34.

Tank, J. L. \& M. J. Winterbourn, 1996. Microbial activity and invertebrate colonisation of wood in a New Zealand forest stream. New Zealand Journal of Marine and Freshwater Research 30: 271-280.

Thomas, J. D. \& P. W. G. Daldorph, 1994. The influence of nutrient and organic enrichment on a community dominated by macrophytes and gastropod mollusks in a eutrophic drainage channel: relevance to snail control and conservation. Journal of Applied Ecology 31: 571-588.

Weyers, H. S. \& K. Suberkropp, 1996. Fungal and bacterial production during the breakdown of yellow poplar leaves in two streams. Journal of the North American Benthological Society 15: 408-420.

Zar, J. H., 1999. Biostatistical Analysis (4th edn). Prentice-Hall International, Inc., New Jersey. 